\title{
Executive Functions and Conscious Self-Regulation as Predictors of Native Language Learning Success in Russian Middle School Children
}

\author{
Varvara I. Morosanovaa, Irina N. Bondarenkoa, \\ Tatiana G. Fomina and Boris B. Velichkovsky*b,c \\ ${ }^{a}$ Psychological Institute of the Russian Academy of Education \\ Moscow, Russian Federation \\ ${ }^{b}$ Lomonosov Moscow State University \\ Moscow, Russian Federation \\ ${ }^{c}$ Moscow State Linguistic University \\ Moscow, Russian Federation
}

Received 09.07.2021, received in revised form 8.08.2021, accepted 10.08.2021

\begin{abstract}
Mastering the mother tongue at school is essential for both academic and life success. It depends on many factors, including self-regulation, i. e. the ability to control one's thoughts and behaviour. In this study, we assess the influence of conscious selfregulation, executive functions (inhibition, switching, working memory updating, and error monitoring and control) and intelligence on Russian language competences and Russian language annual grade in a group of Russian middle school children. Through structural equations modelling, we found that both categories of regulatory predictors, i. e. conscious self-regulation and executive functions, are related to academic performance in the native language. Both predictors make an indirect contribution to the annual grade in the Russian language. In the case of self-regulation, fluid intelligence acts as a mediating variable. Executive functions influence the annual grade through language competences, which also significantly contribute to the general performance. Executive functions also have an impact on self-regulation, confirming their status as the neurocognitive basis of self-regulation. Of the self-regulatory functions, Goal Planning, Modelling, Results Evaluation, and regulatory personality traits of Flexibility and Initiative have the greatest impact on the native language academic performance. We revealed the effect of «excessive flexibility», that is, an increase in number of errors at high values of the executive function Switching attention. Links to recent findings as well as directions for future research are discussed. The results can be used to improve academic performance in native language and emphasize the importance of developing conscious self-regulation at school.
\end{abstract}

Keywords: conscious self-regulation, executive functions, intelligence, language competences, native language.

\footnotetext{
(C) Siberian Federal University. All rights reserved

* Corresponding author E-mail address: tanafomina@mail.ru ORCID: 0000-0001-5539-1027 (Bondarenko); 0000-0001-5097-4733 (Fomina); 0000-0001-7823-0605 (Velichkovsky)
} 
Research area: pedagogy.

Citation: Morosanova, V.I., Bondarenko, I.N., Fomina, T.G. and Velichkovsky B.B. (2021). Executive functions and conscious self-regulation as predictors of native language learning success in russian middle school children. J. Sib. Fed. Univ. Humanit. soc. sci., 14(9), 1342-1354. DOI: 10.17516/1997-1370-0824

\title{
Исполнительные функции и осознанная саморегуляция как предикторы успешности обучения
русскому языку в средней школе
}

\author{
В.И. Моросанова ${ }^{a}$, И.Н. Бондаренко, \\ Т.Г. Фомина, Б.Б. Величковскийб,в \\ ${ }^{a}$ Психологический институт Российской академии образования \\ Российская Федераиия, Москва \\ ${ }^{\sigma}$ Московский государственный университет имени М. В. Ломоносова, \\ Российская Федерачия, Москва \\ ${ }^{6}$ Московский государственный лингвистический университет \\ Российская Федерачия, Москва
}

\begin{abstract}
Аннотация. Овладение родным языком в школе имеет определяющее значение как для академической, так и для жизненной успешности. Этот процесс зависит от многих факторов, включая саморегуляцию как способность сознательно ставить цели и управлять их достижением. В исследовании мы оцениваем влияние осознанной саморегуляции, исполнительных функций (торможение, переключение, обновление рабочей памяти, мониторинг и контроль ошибок) и интеллекта на языковые компетенции и годовую оценку по русскому языку в группе учеников российской средней школы. С помощью моделирования структурными уравнениями мы обнаружили, что обе категории регуляторных предикторов, т. е. осознанная саморегуляция и исполнительные функции, связаны с успеваемостью по родному языку. Оба предиктора вносят опосредствующий вклад в годовую оценку по русскому языку. В случае саморегуляции опосредующей переменной выступает флюидный интеллект. Исполнительные функции влияют на годовую оценку через языковые компетенции, от которых она, в свою очередь, значимо и непосредственно зависит. Исполнительные функции также оказывают влияние на саморегуляцию, подтверждая статус ее нейрокогнитивных оснований. Из компонентов осознанной саморегуляции наибольшее влияние на академическую успеваемость по родному языку оказывают Планирование целей, Моделирование значимых для достижения целей условий, Оценка результатов и регуляторные личностные качества Гибкости и Инициативы. Выявлен эффект «чрезмерной гибкости», то есть увеличения числа ошибок при высоких значениях исполнительной функции Переключения внимания. Результаты обсуждены в контексте полученных ранее данных, а также обозначены направления дальнейших исследований. Полученные результаты могут быть использованы для повышения успеваемости по родному языку; они также подчеркивают значимость развития осознанной саморегуляции у школьников.
\end{abstract}


Varvara I. Morosanova, Irina N. Bondarenko... Executive Functions and Conscious Self-Regulation as Predictors...

Ключевые слова: осознанная саморегуляция, исполнительные функции, интеллект, языковые компетенции, русский язык.

Научная специальность: 13.00 .00 - педагогические науки.

\section{Introduction}

Mastering the first, native language is of the utmost importance in children's education. It is essential for both the advancement in studies and success in later life. Success in first language learning and school studies generally depends on many factors. These include motivation, health, family surrounding, intelligence, and, importantly, self-regulation. Self-regulation (SR, Baumeister et al., 2002) is the ability to alter and control one's thoughts and behaviour and is considered a trait that is extremely important for one's life success. Self-regulation (SR) is related to learning success (Nota, Soresi \& Zimmerman, 2004; Morosanova, Fomina, Kovas \& Bogdanova, 2016; Zimmerman \& Schunk, 2001).

In our studies (Morosanova, Fomina \& Bondarenko, 2015), we differentiate between regulatory-personal and cognitive levels of SR. The regulatory-personal level consists of personality traits that assist the achievement of self- or externally-set goals. The cognitive level consists of processes like planning, situation modelling, action programming, and result evaluation. We suggest that while SR is a high-order construct, it is implemented through executive functions (EFs) on a lower level. EFs are a set of meta-cognitive functions (Diamond, 2013; Miyake, Friedman, Emerson, Witzki, Howerter \& Wager, 2000) which organize goal-directed behaviour in complex situations. The present study aims to analyze the relationship between SR, EFs, and first language competences in a sample of Russian middle school children.

Language competences. Competence is «what a person knows and can do under ideal circumstances» (Messik, 1984, p. 2270. In an educational setting, competences refer to the teaching outcomes related to the proper fulfilment of the later life roles (Gervais, 2016; Glaesser, 2019). The concept of language competences (LCs) has long been a focal is- sue in language teaching. The LC concept is associated with understanding a language as a system and with the acquisition of language norms (Bozhovich, 2016; Kecskes, Sanders \& Pomerantz, 2018). Children build their native language competence by proceeding from specific, distributional, item-based representation to more and more abstract linguistic categories (Lieven, 2008). In this process of linguistic abstraction, formal native language teaching at school plays a crucial role.

The assessment of LCs is a complex problem. Average school marks and exam scores give only very general information about a student's LCs as they depend on other factors beyond language command. To assess LCs, it is necessary to develop a language test to assess how a student uses his/her language knowledge to solve representative tasks in the native (or foreign) language. Such tasks may include locating errors in written texts or producing grammatically well-wormed sentences. Importantly, such representative language tasks must cover a wide range of LCs, from spelling to collocations, depending on the level of language command appropriate for the age in question. Thus, LCs assessment suggests active and productive first language use and not simply a reproduction of linguistic «rules». Assessing LCs based on these principles is very common in Russia (Bozhovich, 2016).

Executive functions. EFs are typically associated with prefrontal lobe functions and are evolutionary a late achievement (Alvarez \& Emory, 2006; Diamond, 2013). They are metacognitive because they do not produce a specific outcome but operate on «specialized» cognitive processes that produce various outcomes, external or mental. Miyake et al. (2000) identified three «basic» EFs: switching, inhibition, and working memory updating. The switching function is related to cognitive flexibility allowing for switching between different tasks. Inhibition is a system of functions allowing for 
a voluntary decrease in the activation of representations and responses. Inhibition plays an essential role in the organization of purposeful behaviour and self-control. Working memory updating is used for the storage and processing of operative information. Working memory updating may play an important role in the storage of action plans and situational mental models. Additionally, we measured error monitoring and correction. The error monitoring and correction EF is associated with the quality of cognitive activity and is indispensable for closed-loop self-regulation (Dutilh, Vandekerckhove, Forstmann, Keuleers, Brysbaert \& Wagenmakers. 2012).

$S R$. In our studies, conscious selfregulation is characterized as a cognitivepersonal construct. On the one hand, it represents a system of cognitive mechanisms for information processing, including planning, modelling, programming, and results evaluation. On the other hand, the distinctive feature of these processes (their individual profile) at the personality level is representation through a number of instrumental personal-regulatory properties: flexibility, independence, reliability, etc. This structure emphasizes the metanature of conscious self-regulation as a psychological means of mobilizing and integrating cognitive and personality resources to resolve various tasks of human activity.

Relationships between $E F, S R$, and $L C$. Effective SR and EFs are related to each other in different activities, including academic learning (Hofmann, Schmeichel \& Baddeley, 2012; Welsh \& Peterson, 2014). In particular, SR is important for successful foreign language learning (Tsuda \& Nakata, 2012; Gorgoz \& Tican, 2020). There is also a link between effective SR and successful native language learning at school (Bondarenko, Fomina \& Morosanova, 2020). Researchers have also often suggested a link between EFs and language (Marslen-Wilson \& Tyler, 2007; Veraksa, Bukhalenkova \& Koviazina, 2018). Studies on cognitive language learning factors suggested that EFs are related to native and foreign language learning at school (e. g., Gooch, Thompson, Nash, Snowling \& Hulme, 2016). However, a recent Russian study on the contribution of EF to native language learning in school (Verbitskaia, Malykh, Zynchenko \& Tikhomirova, 2015) failed to find a link between an EF (working memory) and language exam grades in a sample of Russian schoolchildren. This null result can be related to the specific EF measures used. In any case, how EFs and SR are linked in producing different LCs (lexical, syntactic, etc.) have not been investigated enough. In the current study, we explicitly assess the links between EFs, SR, and LCs in the native language in a sample of Russian seventh and ninth graders.

\section{Method}

Participants. The study was performed on a group of state secondary school students from Moscow and the Moscow Region aged $13-15(\mathrm{~N}=286)$ : seventh graders $(\mathrm{N}=147$, mean age $13 \pm 0,5$ years $)$ and ninth graders $(\mathrm{N}=139$, mean age $15 \pm 0.5$ years). Gender was distributed almost evenly within the sample group (50.3\% female).

Self-regulation Measure. To assess conscious self-regulation development, the «SelfRegulation Profile of Learning Activity Questionnaire - SRPLAQ» was used (Morosanova $\&$ Bondarenko, 2015). It consists of 67 statements describing typical situations of achieving educational goals which generate 10 scales: planning (e. g. «I often try to set a certain amount of time needed to complete a learning task»); modelling (e. g. «Unexpected changes in the timetable throw me off my stride»); programming (e. g. «When preparing for a test (exam), I usually think over the order of studying the material»); results evaluation (e. g. «Even when I'm tired, I tend to study until I'm satisfied with the result»); flexibility (e. g. «If I need to get prepared for a class, I can work even in an uncomfortable and unfamiliar situation»), initiative (e. g. «I use every opportunity to make reports in class»); reliability (e. g. «I do not postpone studying even if I'm tired or sick»), responsibility (e. g. «I do not give up preparing for classes even if I have to choose between studying and spending time with my friends»), social desirability (e. g. «I always admit my mistakes») and the general level of selfregulation. SRPLAQ was previously validated 
in a sample group of 14-18-year-old students $(\mathrm{N}=702)$. The validation study showed that coefficients of internal consistency of items for each scale ranged from 0.58 to 0.76 , indicating an overall reasonable homogeneity of the items in each scale. The subscales were significantly correlated with each other $(\mathrm{r}=0.22-0.66$, $\mathrm{p}<0.001)$. The responses to each statement are given on a 4 point scale (Yes - Probably Yes Probably No - No). The responses are then reduced to only «Yes» and «No» by counting «probably yes/probably no» as «yes/no», respectively. The «yes» responses are then added up (items are reversed if necessary) so that the high scores (maximum 9 for each scale) denote high self-regulation.

EF measures. We used three standard tasks for the assessment of basic EFs (Miyake et al., 2000). To assess inhibition, we used the Eriksen Flanker task. The stimuli are five horizontally arranged black arrows presented against a white background in two conditions: a congruent condition $(>>>>>,<<<<<$ ) and an incongruent condition $(>><>>,<<><<)$. The respondent's task is to attend to the arrow in the middle and to indicate its direction by pressing the corresponding key («z» for left and «/» for right). A training session comprised of 36 trials is included. The main series contains four blocks of 36 unique trials in each. The maximum response time is $1,500 \mathrm{~ms}$. The response to stimulus interval is fixed at $1,000 \mathrm{~ms}$. Four response parameters are registered: average reaction time, percentage of correct answers, the difference in reaction time and accuracy between the congruent and noncongruent trials (the interference effect).

To assess switching, we used the LetterNumber task with predictable task changes. The task shows a white screen divided into four quadrants. A pair of symbols, a digit and a letter, is presented clockwise in each quadrant, starting from the upper left. The respondent's task is to determine whether the digit is even or odd if the characters are located in one of the upper quadrants and whether the letter is a consonant or a vowel if the symbols appear in one of the lower quadrants. The answer is given by pressing a key («Z» for odd digits and vowel letters and «/» for even digits and con- sonant letters). The training series consists of 24 letter-digit pairs. The main series consists of 128 trials. The stimuli remain on the screen until the response is given. The response to stimulus interval is $500 \mathrm{~ms}$. Six response parameters are registered: average reaction time and accuracy, repetition trials' reaction times and accuracy, switching trials' reaction times and accuracy, and two switch costs indicating switching efficiency (the differences in reaction time and accuracy between switching and repetition trials).

To evaluate working memory updating, we used the N-Back task. The digits from 1 to 8 are presented in a pseudo-random order. The respondent's task is to answer quickly and correctly whether the currently presented digit coincides with the digit presented two positions before (2-back). The training series contains 32 trials, and the two main series each contain 48 trials. Each figure appears six times in each series (four times in the training series), once as a target. Stimulus presentation time is 500 $\mathrm{ms}$. The inter-stimulus interval is $2,000 \mathrm{~ms}$. The answer is given by pressing a key (《/» for yes or $\langle\mathrm{Z}\rangle$ for no). Average reaction time, accuracy, reaction times and counts for different response types (hits, correct rejections, false alarms, and misses) are recorded.

To assess error correction, we computed the post-error slowing (PES) effect. PES (Dutilh et al., 2012) is the effect of trials after an incorrect trial exhibiting longer reaction times. The PES effect is associated with the activity of the conscious error monitoring and correction system within the anterior cingulate cortex (Botvinick, Braver, Barch, Carter \& Cohen, 2001). We computed PES by subtracting the average reaction time from the average reaction time in the post-error trials in each EF task.

LC measures. We used two tasks for LC diagnostics (Bozhovich, 2016). The first task consists of 20 sentences printed on a sheet of paper. The sentences include eight types of errors: spelling (misspelt words), punctuation (a sign at the end of a sentence), morphological (incorrect word forms), lexical (incorrect collocations), syntactical (improper connection between words), semantic-syntactical (use of a structure that does not correspond to the 
content of sentence), semantic (the content of the sentence does not correspond to the nonlinguistic reality), and stylistic errors (wrong choice of words, sentence structure, word order, word combinations, etc.). Each sentence contains one error. Each type of error is contained in two sentences. There is no more than one error in a sentence, so there are 16 sentences with errors and four distracter sentences without errors. The respondent's task is to find errors in the sentences and mark them on the sheet.

The second task requires active transformation of language elements. It also consists of 20 sentences; 16 sentences contain the eight types of errors from the first task. Similarly to Task 1 , four sentences do not contain any errors. The respondent's task is to copy the sentence to the answer sheet if there are no errors; if there is an error, the respondent is expected to rewrite the sentence, correcting it. No time limits were imposed in Tasks 1 and 2. The collected data are compared with an answer key, and error omissions are evaluated according to the «cost» of an error: spelling and punctuation errors add three points to the LC score; morphological, syntactical, syntactic-semantic, semantic, lexical, and stylistic errors add two points; and «false alarms» (wrongly recognized errors) add one point. According to the type of error, errors made in the rewritten sentences are indicated as an additional measure. Overall LC scores (computed separately for Task 1 and 2) range from 0 to 60 . A separate score is computed for each competence (given by error type). A higher LC score is indicative of less competent language use.

Procedure. The students performed tasks for the assessment of LC, SR, and intelligence in the classroom. Computerized tasks for EF assessment were performed at a computer lab on another day. The study was conducted in accordance with the Helsinki Declaration. Ethical agreement and consent for access to school were provided by the XXX and approved by the local ethic committee (protocol no. 2018/218 , research project «Conscious self-regulation in the system of cognitive and non-cognitive mechanisms of success in learning Russian at school»).

\section{Data Analytic Plan or Analytic Strategy}

All analyses were performed using SPSS version 26. Exploratory factor analysis was used to reduce the number of analyzed variables. We factorized all EF indicators using the method of principal components with VARIMAX rotation. Similar analyses were performed separately for LC measures for each of the two LC tasks. AMOS19 (Analysis of Moment Structures) software was used to test the structural equation modelling model of interrelation between EFs, SR, and LCs in native language use.

\section{Results}

Data reduction. Due to a large number of EF indicators, a data reduction procedure was applied. First, standardized data on EF were submitted to a factor analysis with VARIMAX-rotation. Then, factors were extracted based on Kaiser's rule (eigenvalue over one). In total, ten factors for $74 \%$ of the variance were extracted (Table 1). The factors reflected the basic EFs (inhibition, switching, updating, and error correction) quite well. However, for most basic EFs, an RT and an accuracy factor were extracted.

Factor 1 is dominated by the accuracy inhibition indicators with some influence of working memory updating. This is not surprising as working memory function and inhibitory control are closely related. Therefore, we call this the Inhibition factor. It is related to the ability to suppress unwanted representations and stimuli, that is, to the control of internal and external attention. Factor 2 is composed of switching accuracy indicators and is therefore called Switching Accuracy. It is related to cognitive flexibility, i. e. the ability to change between tasks and representations quickly. In the same vein, Factor 3 is called Updating Accuracy. It is related to the ability to hold and processes cognitive representations in working memory. Factor 4 is also clearly composed of working memory updating indicators (but they are related to the processing speed of representations in working memory). We call this factor Updating Efficiency. Factor 5 is composed of switching RT indicators and is therefore called Switching Efficiency. Factors 6, 9, and 10 all 
Table 1. Factor Analysis for EF Measures

\begin{tabular}{|c|c|c|c|c|c|c|c|c|c|c|}
\hline & \multicolumn{10}{|c|}{ Factors } \\
\hline Indicators & 1 & 2 & 3 & 4 & 5 & 6 & 7 & 8 & 9 & 10 \\
\hline I/ACC(congruent) & .918 & & & & & & & & & \\
\hline $\mathrm{I} / \mathrm{ACC}$ & .823 & & & & & & .455 & & & \\
\hline I/RT & .810 & & & & & & & & & \\
\hline U/ACC(misses) & .741 & & & & & & & & & \\
\hline U/RT(hits) & .503 & & & & & & & & & \\
\hline S/ACC(repeat) & & .959 & & & & & & & & \\
\hline S/ACC & & .957 & & & & & & & & \\
\hline S/ACC(switch) & & .941 & & & & & & & & \\
\hline $\mathrm{U} / \mathrm{ACC}$ & & & .850 & & & & & & & \\
\hline U/ACC(FAs) & & & .845 & & & & & & & \\
\hline $\mathrm{U} / \mathrm{ACC}(\mathrm{CRs})$ & & & -.816 & & & & & & & \\
\hline U/ACC(hits) & & & -.517 & & & & & & & \\
\hline $\mathrm{U} / \mathrm{RT}$ & & & & .926 & & & & & & \\
\hline $\mathrm{U} / \mathrm{RT}(\mathrm{CRs})$ & & & & .891 & & & & & & \\
\hline $\mathrm{U} / \mathrm{RT}$ (misses) & & & & .719 & & & & & & \\
\hline U/RT(FAs) & & & & .609 & & & & & & \\
\hline $\mathrm{S} / \mathrm{RT}$ & & & & & .989 & & & & & \\
\hline $\mathrm{S} / \mathrm{RT}$ (switch) & & & & & .937 & & & & & \\
\hline S/RT(repeat) & & & & & .891 & & & & & \\
\hline $\mathrm{I} / \mathrm{CA}$ & & & & & & .920 & & & & \\
\hline I/PES & & & & & & .852 & & & & \\
\hline I/ACC(incongruent) & & & & & & & .812 & & & \\
\hline I/Interference & & & & & & & -.755 & & & \\
\hline $\mathrm{S} / \operatorname{Cost}(\mathrm{RT})$ & & & & & & & & .746 & & \\
\hline I/CA & & & & & & & & -.723 & & \\
\hline S/PES & & & & & & & & & -.729 & \\
\hline I/PES & & & & & & & & & .531 & \\
\hline $\mathrm{S} / \operatorname{Cost}(\mathrm{ACC})$ & & & & & & & & & .497 & \\
\hline U/PES & & & & & & & & & & -.602 \\
\hline I/RT(incongruent) & & & & & & & & & & .401 \\
\hline
\end{tabular}

Notes. $U$ = Updating. $S=$ Switching. $I=$ Inhibition. $\mathrm{RT}=$ Reaction time. $\mathrm{ACC}=$ Accuracy. PES = Post-error slowing. $\mathrm{CR}=$ Correct rejections. Cost(Errors) $=$ Error-related switch cost.

include various indicators of conflict and error monitoring and resolution (conflict adaptation and post-error slowing measures). Based on its composition, Factor 6 is called Conflict Adaptation and Factors 9 and 10 are called Error Resolution 1 and 2, respectively. They are all related to the ability to monitor for conflicts and errors and to recover from them. All these factors presumably assess functions ascribed to the anterior cingulate cortex. Factor 7 is clearly an Interference Control factor comprised of accuracy indicators of how god interference is controlled in the flanker task. This factor is related to the effectiveness of attention control. 
Table 2. Factor Analysis for LC Measures

\begin{tabular}{lcccc}
\hline \multicolumn{1}{c}{ Indicators } & $\begin{array}{c}\text { Language } \\
\text { Command (1) }\end{array}$ & $\begin{array}{c}\text { Word } \\
\text { Structure (2) }\end{array}$ & $\begin{array}{c}\text { Fentence } \\
\text { Structure (3) }\end{array}$ & Sense factor (4) \\
\hline Style & .726 & & & \\
Semantics & .668 & & & \\
Lexical & .640 & & & \\
Morphology & & .940 & & \\
Spelling 1 & .368 & .625 & .674 \\
Spelling & & .482 & .334 \\
Punctuation 1 & & & & \\
Syntax & & & & \\
Sense & & & & \\
Punctuation & & & & \\
\hline
\end{tabular}

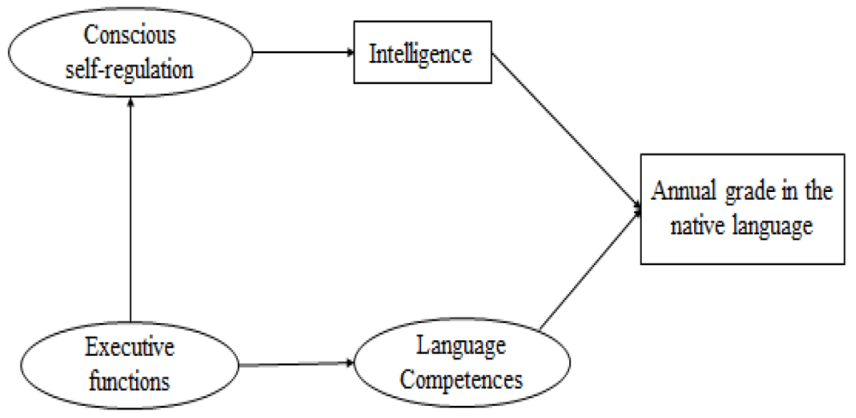

Fig. 1. The conceptual model of the relationship between EFs, SR, and LC

Factor 8 is complex in its interpretation as it comprises a switching efficiency indicator and a conflict monitoring indicator. As switching involves a lot of conflicts, we call it the Cognitive Flexibility factor.

We also applied a data reduction procedure to language competences (LC) data. LC data from both LC tests were submitted to an alpha factor analysis with Equimax rotation and Kaiser's normalization. As a result, a factor solution (eigenvalues over 1) with four factors was obtained (see Table 2 for factor loadings, only indicators over 0.3 are presented), explaining $67 \%$ of the variance.

Factor 1 is dominated by semantic-lexical aspects of language use and is therefore called Language Command. Factor 2 comprises spelling and morphology competences that relate to the word level of the grammatical structure.
It is therefore called Word Structure. Factor 3 is comprised of spelling, punctuation, but also syntax indicators, so we call it Sentence Structure. Last, Factor 4 is dominated by the semantics and pragmatics of the sentences («meaning/sense»), so we call it the Sense factor.

Structural equation modelling. The conceptual model of the relationship between EFs, $\mathrm{SR}$, and LCs is presented in Figure 1.

Various structural models were fitted using the AMOS software. The best-fitting model is presented in Figure 2. The fit indices for this model were good to excellent: $\chi^{2} / \mathrm{df}=1.19$; $\mathrm{p}=0.04 ; \mathrm{GFI}=0.92 ; \mathrm{CFI}=0.95 ; \mathrm{RMSEA}=0.029$; Pclose $=0.99$.

\section{Discussion}

$S R, E F$, and Native Language Learning

Success. The resulting structural model re- 


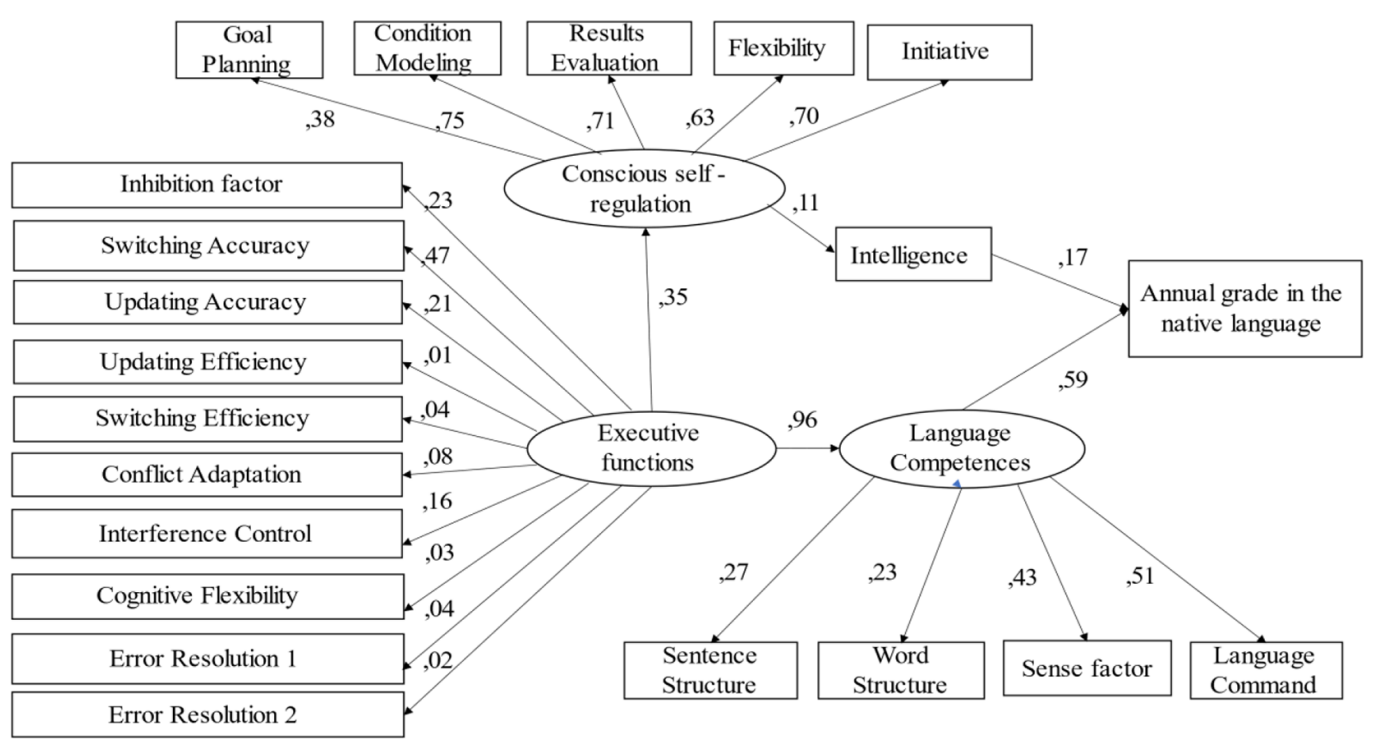

Fig. 2. Structural model of the relationship between EFs, SR, and LCs

vealed the specific contribution of regulatory predictors - conscious SR and EF to academic performance in the native language. Both indicators make an indirect contribution to the annual grade in the Russian language. In the first case, fluid intelligence $(\beta=.17)$ acts as a mediating variable. EF influence the annual grade $(\beta=.96)$ through the Language Competences, whose contribution, in turn, is quite significant $(\beta=.59)$. The model assesses EFs' contribution to the conscious SR $(\beta=.35)$, confirming results of the previous studies on the relationship between SR and EF (e. g., Welsh \& Peterson, 2014 Kaplan, Lichtinger \& Gorodetsky, 2009; Skibbe, Montroy, Bowles \& Morrison, 2019). Researchers agree that the metacognitive levels of SR and EF are closely related developmentally (Roebers \& Feurer, 2016). It is worth noting that our result was obtained from a sample of middle school students. Such studies are very rare for the native language subject.

Conscious self-regulation in this model is represented by the regulatory processes of Goal Planning, Condition Modelling, and Results Evaluation, as well as the regulatory personality traits of Flexibility and Initiative. Including these indicators into the model allowed for confirming results of the previous studies (Bondarenko, Fomina \& Morosanova, 2020) and reveals the mechanism of the regulatory predictors' influence on the annual grade in the native language. Successful learners plan their own goals, take advantage of conditions relevant for achieving the goals, are sensitive to feedback from their teachers, flexibly cope with obstacles and participate in additional learning activities. These results obtained are in good agreement with the few foreign data on the influence of the Self-Regulated Learning on native language proficiency (Zimmerman, Schunk, 2001; Kaplan, Lichtinger \& Gorodetsky, 2009; Rutherford, Buschkuehl, Jaeggi $\&$ Farkas et al., 2018). Longitudinal studies also revealed that children who developed the ability to self-regulate early demonstrated higher literacy and language skills, better reading comprehension, were more successful in phonetics, and had a broader vocabulary (Skibbe \& Foster, 2019).

A theoretical basis for the work of Limpo, Alves, and Fidalgo in analyzing high-level writing skills was the model proposed by Hayes and Flower in 1980 (Limpo et al., 2014; Hayes, Flower, 1998). They assumed that there are three different processes governing writing: planning, translation and proofreading, which is close to our theoretical model of conscious self-regulation. Moreover, there are intrigu- 
ing results obtained by Limpo and colleagues, which indicate a change in the size of the contribution of planning and evaluation processes in grades 4-9 (Limpo et al., 2014). Allen, Snow, and McNamara reported on the positive contribution of Flexibility to academic performance: better writing is associated with higher flexibility, which, in turn, is a function of individual differences associated with writing skills such as vocabulary and general knowledge (Allen et al., 2015).

$\boldsymbol{E F}$ and $\boldsymbol{L C}$. Research on the relationship between EFs and various LCs has shown that phonological awareness is associated with retaining speech sounds in the working memory (Lonigan, 2009). At the same time, it has been demonstrated that academic skills requiring more complex coordination (e. g., writing comprehension) are more associated with conscious regulation (Bondarenko, Fomina \& Morosanova, 2020). LCs in our model are represented by all four indicators, the most significant of which is Language Proficiency. Since it is made up of the high-level semantic indicators of the written language proficiency associated with stylistically and lexically correct sentence organization, we believe that Language Proficiency characterizes the so-called Sense of Language (language proficiency and ability to apply it depending on the situation, largely intuitively without relying on the formal rules knowledge (Bozhovich, 2016). It is important to note that EFs, contrary to LCs, do not directly contribute to the annual grade in the Russian Language in the middle and high school periods. Recently, Rutherford and colleagues came to similar conclusions (Rutherford et al., 2018). However, establishing EFs mediator contribution through LCs has theoretical and practical implications.

$S R$, Intelligence and Native Language Learning Success. Another contribution to determining performance in the native language is made by intelligence. It was found that, unlike mathematics, where intelligence plays a leading role in ensuring high grades, academic performance in the Russian language depends on intelligence to a much lesser extent. Bondarenko, Potanina, Morosanova (2020) have revealed that with an average and high level of the regulatory process of Conditions Modelling, an increase in the intelligence level leads to a decrease in writing mistakes. However, high intelligence with a low level of Modelling does not guarantee a decrease in errors. It may be the reason why we can observe similar effects in gifted students (Morosanova, Fomina \& Bondarenko, 2015).

\section{Limitations and Future Directions}

Our findings concerning the regulatory feature of flexibility differ from those found by Allen, Snow, and McNamara: better writing is associated with higher flexibility, which, in its turn, is a function of individual differences associated with writing skills such as vocabulary and erudition (Allen et al., 2015). The results obtained in our study demonstrated that when it comes to regulatory flexibility, such an indicator of the cognitive level of conscious self-regulation as switching is of particular importance. The more efficiently a student switches from one task to another, the more syntax errors he makes. The study revealed the phenomenon of «excessive flexibility» leading to errors and reducing them a deliberate slowdown in the pace of doing a task (requires further research).

\section{Conclusions}

The results of structural modelling gave us grounds for confirming the hypothesis on the regulatory predictors of academic performance in native language learning. Research results indicate a significant contribution of the conscious SR to academic achievement in the mother tongue. The study revealed that the basic neurocognitive level of self-regulation, represented by EFs, acts in two ways. On the one hand, EFs are primarily responsible for acquiring LCs in certain areas of native language learning. On the other hand, EFs are interconnected with the conscious SR of learning activity through which they indirectly influence academic performance as well. The results obtained can be used to create psychological interventions and teaching technologies aimed both at developing students' LCs and improving their conscious SR of the learning activity. 


\section{References}

Allen, L. K., Snow, E. L. \& McNamara, D. S. (2016). The narrative waltz: The role of flexibility in writing proficiency, In: Journal of Educational Psychology, 108(7), 911-924. http://dx.doi.org/10.1037/ edu0000109

Alvarez, J. A. \& Emory, E. (2006). Executive function and the frontal lobes: a meta-analytic review, In: Neuropsychology Review, 16(1), 17-42. https://doi.org/10.1007/s11065-006-9002-x

Baumeister, R.F., Leith, K.P., Muraven, M., Bratslavsky, E. (2002). Self-Regulation as a Key to Success in Life. In: Pushkar D., Bukowski W.M., Schwartzman A. E., Stack D. M., White D. R. (eds) Improving Competence Across the Lifespan (pp. 117-132). Boston, MA.: Springer, https://doi.org/10.1007/0-30647149-3_9

Bondarenko, I., Fomina, T., Morosanova, V. (2020). Regulatory predictors of linguistic competences and academic achievement in native language among secondary school students, In: European Proceedings of Social and Behavioural Sciences EpSBS. 91. 148-155. https://doi.org/10.15405/epsbs.2020.10.04.19

Bondarenko, I.N., Potanina, A.M. \& Morosanova, V.I. (2020). Conscious self-regulation as a resource for success in the Russian language in students with different levels of intelligence, In: Experimental Psychology (Russia), 13(1), 63-78. doi:10.17759/exppsy.2020130105

Botvinick, M.M., Braver, T.S., Barch, D.M., Carter, C.S. \& Cohen, J.D. (2001). Conflict monitoring and cognitive control, In: Psychological Review, 108(3), 624-652. https://psycnet.apa.org/doi/10.1037/0033295X.108.3.624

Bozhovich, E.D. (2016). Razvitie iazykovoy kompetentsii kak psikhologicheskoy sistemy [The development of language competence as a psychological system]. Extended abstract of doctor's thesis. Moscow. (In Russian).

Diamond, A. (2013). Executive functions, In: Annual review of psychology, 64, 135-168. https://doi. org/10.1146/annurev-psych-113011-143750

Dutilh, G., Vandekerckhove, J., Forstmann, B.U., Keuleers, U., Brysbaert, M. \& Wagenmakers, E.-J. (2012). Testing theories of post-error slowing, In: Attention, Perception, and Psychophysics, 74(2), 454465. https://doi.org/10.3758/s13414-011-0243-2

Gervais, J. (2016). The operational definition of competency-based education, In: The Journal of Competency-Based Education. 1(2), 98-106. https://doi.org/10.1002/cbe2.1011.

Glaesser, J. (2019). Competence in educational theory and practice: a critical discussion, In: Oxford Review of Education, 45(1), 70-85. https://doi.org/10.1080/03054985.2018.1493987

Gooch, D., Thompson, P., Nash, H.M., Snowling, M.J. \& Hulme, C. (2016). The development of executive function and language skills in the early school years, In: Journal of Child Psychology and Psychiatry, 57(2), 180-187. https://doi.org/10.1111/jcpp.12458

Gorgoz, S. \& Tican, C. (2020). Investigation of middle school students' self-regulation skills and vocabulary learning strategies in foreign language, In: International Journal of Educational Methodology, 6(1), 25-42. https://doi.org/10.12973/ijem.6.1.25

Hofmann, W., Schmeichel, B.J. \& Baddeley, A.D. (2012). Executive functions and self-regulation, In Trends of Cognitive Science, 16(3), 174-180. http://dx.doi.org/10.1016/j.tics.2012.01.006

Kaplan, A., Lichtinger, E. \& Gorodetsky, M. (2009). Achievement of goal orientations and selfregulation in writing: An integrative perspective, In: Journal of Educational Psychology, 101(1), 51-69. https://psycnet.apa.org/doi/10.1037/a0013200

Kecskes, I., Sanders, R. E. \& Pomerantz, A. (2018). The basic interactional competence of language learners, In: Journal of Pragmatics, 124, 88-105. https://doi.org/10.1016/j.pragma.2017.10.019

Lieven, E. (2008). Building language competence in first language acquisition, In: European Review, 16(4), 445-456 doi:10.1017/S1062798708000380

Limpo, T., Alves, R. A. \& Fidalgo, R. (2014). Children's high-level writing skills: Development of planning and revising and their contribution to writing quality, In British Journal of Educational Psychology, 84(2), 177-193. https://doi.org/10.1111/bjep.12020 
Lonigan, C.J., Anthony, J.L., Phillips, B.M., Purpura, D.J., Wilson, S.B. \& McQueen, J.D. (2009). The nature of preschool phonological processing abilities and their relations to vocabulary, general cognitive abilities, and print knowledge, In: Journal of educational psychology, 101(2), 345-358. https://psycnet.apa. org/doi/10.1037/a0013837

Marslen-Wilson, W.D. \& Tyler, L.K. (2007). Morphology, language and the brain: The decompositional substrate for language comprehension, In: Philosophical Transactions of the Royal Society: Biological Sciences, 362, 823-836. https://doi.org/10.1098/rsth.2007.2091

Miyake, A., Friedman, N.P., Emerson, M.J., Witzki, A.H., Howerter, A. \& Wager, T.D. (2000). The unity and diversity of executive functions and their contributions to complex «frontal lobe» tasks: A latent variable analysis, In: Cognitive psychology, 41(1), 49-100. https://doi.org/10.1006/cogp.1999.0734

Morosanova, V.I. \& Bondarenko, I.N. (2015). Diagnostika samoreguliatsii cheloveka [Diagnostics of self-regulation in individuals]. Moscow: Kogito-Tsentr.

Morosanova, V.I., Fomina, T.G., Kovas, Y. \& Bogdanova, O.Y. (2016). Cognitive and regulatory characteristics and mathematical performance in high school students, In: Personality and Individual Differences, 90, 177-186. https://doi.org/10.1016/j.paid.2015.10.034

Morosanova, V.I., Fomina, T. \& Bondarenko, I.N. (2015). Academic achievement: Intelligence, regulatory, and cognitive predictors, In: Psychology in Russia, 8(3), 136. https://doi.org/10.11621/ pir.2015.0311

Morosanova, V.I (2014). Osoznannaia samoreguliatsiia cheloveka kak psikhologicheskii resurs dostizheniia uchebnykh i professional'nykh tseley [Conscious self-regulation of personal activity as a psychological resource for achieving goals], In: Theoretical and experimental psychology [Teoreticheskaia i eksperimental'naia psikhologiia], 7(4). 16-38 http://www.tepjournal.ru/images/pdf/2014/4/07.pdf

Morosanova. V.I., Bondarenko. I.N. \& Fomina T. G. (2019). Vklad ispolnitel'nykh funktsiy i osoznannoy samoreguliatsii v uspeshnost' po russkomu iazyku v sredney shkole [Contribution of executive functions and conscious self-regulation to success in the Russian language in secondary school], In: Theoretical and experimental psychology [Teoreticheskaia i eksperimental'naia psikhologiia], 12(4). 54-66. http://www. tepjournal.ru/images/pdf/2019/04/06.pdf

Nota, L., Soresi, S. \& Zimmerman, B.J. (2004). Self-regulation and academic achievement and resilience: A longitudinal study, In: International journal of educational research, 41(3), 198-215. https://doi. org/10.1016/j.ijer.2005.07.001

Roebers, C.M. \& Feurer, E. (2016). Linking executive functions and procedural metacognition, In: Child Development Perspectives, 10(1), 39-44. https://doi.org/10.1016/j.dr.2017.04.001

Rutherford, T., Buschkuehl, M., Jaeggi, S.M. \& Farkas, G. (2018). Links between achievement, executive functions, and self-regulated learning, In: Applied Cognitive Psychology, 32(6), 763-774. https:/doi. org/10.1002/acp.3462

Skibbe, L.E. \& Foster, T.D. (2019). Participation in the Imagination Library book distribution program and its relations to children's language and literacy outcomes in kindergarten, In: Reading Psychology, 40(4), 350-370. https://doi.org/10.1080/02702711.2019.1614124

Skibbe, L. E., Montroy, J. J., Bowles, R. P. \& Morrison, F. J. (2019). Self-regulation and the development of literacy and language achievement from preschool through second grade, In: Early childhood research quarterly, 46, 240-251. https://doi.org/10.1016/j.ecresq.2018.02.005

Tsuda, A. \& Nakata, Y. (2013). Exploring self-regulation in language learning: A study of Japanese high school EFL students, In: Innovation in Language Learning and Teaching, 7(1), 72-88. https://doi.org/ 10.1080/17501229.2012.686500

Velichkovsky, B.B., Bondarenko, I.N. \& Morosanova, V.I. (2019). The relationship between executive functions and language competences in middle school children, In: Psychology in Russia: State of the art, 12(1). 104-117. https://doi.org/10.11621/pir.2019.0108

Veraksa, A.N., Bukhalenkova, D.A. \& Koviazina, M.S. (2018). Language proficiency in preschool children with different levels of executive function, In: Psychology in Russia: State of the art, 11(4). DOI: 10.11621/pir.2018.0408 
Verbitskaia, L.A., Malykh, S.B., Zinchenko, Iu.P. \& Tikhomirova, T.N. (2015). Cognitive predictors of success in learning Russian, In: Psychology in Russia: State of the Art, 8(4), 91-100. http://doi.org/10.11621/ pir.2015.0408

Welsh, M. \& Peterson, E. (2014). Issues in the conceptualization and assessment of hot executive functions in childhood, In: Journal of the International Neuropsychological Society, 20(2), 152-156. https://doi. org $/ 10.1017 /$ S1355617713001379

Zimmerman, B.J. \& Schunk, D.H. (Eds.). (2001). Self-regulated learning and academic achievement: Theoretical perspectives. London, Routledge, $484 \mathrm{p}$. 